\title{
Effect of inclusion of NDF in ration of Bergamasca ewes in lactation about the milk production and composition
}

\author{
A S Natel ${ }^{1}$, E R Siqueira ${ }^{1}$, P R Meireles ${ }^{2}$, M B Martins ${ }^{2}$, M T Almeida ${ }^{1}$, S \\ Fernandes ${ }^{1}$ \\ ${ }^{1}$ Department of Animal Production, FMVZ/UNESP (Lageado Farm, Cx. P. 560, CEP: 18.618-000, \\ Botucatu/SP), Brazil \\ ${ }^{2}$ Department of Nutrition and Animal Breeging, FMVZ/UNESP (Lageado Farm, CX. P. 560, CEP: 18.618-000, \\ Botucatu/SP), Brazil
}

\begin{abstract}
Ruminant milk composition is directly affected by diet, which can interfere in rumen fermentation and in the availability of precursors for the synthesis of fat, protein and lactose. This study evaluated the effect of the inclusion of neutral detergent fiber (NDF) on dry matter intake, feed efficiency, milk production and composition of Bergamácia ewes. Sixteen lactating ewes were divided into four $4 x 4$ Latin squares. The experimental diets consisted of protein concentrate and alfalfa hay. Concentrate:forage ratios varied according to treatment, to achieve the required levels of NDF: (T1) 23\%, (T2) 32\%, (T3) $41 \%$ and (T4) 50\% NDF in total ration. The ewes were milked twice a day in a milking machine. Milk samples were collected for two days in each sub-period to determinate the composition by infrared method. There was a linear effect $(P<0.01)$ in milk production and average daily production efficiency $(P<0.02)$ with the inclusion of fiber in the diet. A quadratic effect was observed for DMI (1.69, 1.71, 1.58 and 1.32 kilograms). Increasing fiber in the diet reduced milk production without altering its composition. The maximum intake was achieved at $37.8 \%$ NDF in the ration.
\end{abstract}

Keywords - dry matter intake; lactation; Neutral Detergent Fibre; efficiency

\section{INTRODUCTION}

Fiber plays an important role as an essential component of ruminant diets, providing substrate and energy for microbial fermentation in the rumen, regulating fat content in milk and controlling dry matter intake (DMI). However, due to the low-digestibility of the fiber (NDF), it can limit DMI and negatively affect milk production when included at excessive levels in the diet [1].

While evaluating the nutrient intake and performance of dairy sheep, observed a decrease in milk production as NDF levels increased [2]. Likewise, changes to fiber concentrations in the diet can affect the composition of milk, particularly with regard to fat levels [3]. Cows in mid-lactation, obtained maximum production of $4 \%$ fat-corrected milk when the animals were fed diets containing around 27\% NDF [4]. Protein levels in sheep milk showed maximum estimated production at the level of $43 \%$ NDF in diet [5].

The composition of milk from ruminants is directly affected by diet, which can interfere in rumen fermentation and in the availability of precursors for the synthesis of fat, protein and lactose. A reduction in diet fiber levels leads to lower rumen $\mathrm{pH}$, due to the reduction in rumination/chewing time, therefore, results in a decreased flow of saliva to the rumen, reducing the flow of buffering substances, affecting the acetate:propionate ratio and thus impacting milk fat levels [3]. In that sense, it is important to highlight the preponderant physical effectiveness effect of dietary fiber on the percentage of fat in milk.

Therefore, it is fundamentally important to know the characteristics of different feed items and their balancing in rations, which should be formulated to provide for the needs of animals by exploiting their maximum digestive and productive capacity. In that context, the objective of this work was to evaluate the effect of including increasing levels of NDF in total mixed rations for dairy ewes on dry matter intake, milk yield and composition.

\section{MATERIAL AND METHODS}

The experiment was carried out at São Paulo State University (UNESP), College of Veterinary Medicine and Animal Science, Botucatu Campus, at the facilities of the Sheep Milk Production Research Unit, during the months of June to November, winter and spring season.

A total of 16 multiparous ewes of Bergamasca breed were used, averaging three years of age, $60 \mathrm{~kg}$ of body weight, with about 30 days of lactation and average daily milk production of $0.4 \mathrm{~kg}$.

The animals were allotted in a quadruple 4 x 4 Latin-square experimental design, so that each ewe went through all treatments. The experimental period lasted 88 days, divided into four sub-periods of 22 days, with 14 days for adjustment to the experimental treatments, seven days for sample collections, and one day for evaluation of ingestive behavior. 
The experimental treatments were defined by the inclusion of increasing levels of NDF in total mixed ration: 1) $23 \% \mathrm{NDF}$; 2) $32 \% \mathrm{NDF}$; 3) $41 \% \mathrm{NDF}$; and 4) $50 \% \mathrm{NDF}$.

The diets consisted of concentrate and alfalfa hay, and were developed according to requirements for lactating ewes [6].

The roughage:concentrate ratio varied depending on treatment, in order to reach the desired NDF level for the experimental diets (Table 1). Alfalfa hay was chopped to $3 \mathrm{~mm}$ for better homogenization of the total diet and to avoid selection by the ewes.

Daily after the morning milking (9 a.m.), the total mixed rations (Table 1) were weighed individually on an electronic scale with $1 \mathrm{~g}$ precision, and offered at libitum. Leftovers in each stall were weighed between the 15 th and 21 st days of each sub-period to obtain the DMI per animal. In that period the leftovers were quantified, a sample of $10 \%$ was collected and stored at $-18^{\circ} \mathrm{C}$ for later analysis.

Measurements of dry matter (DM), crude protein (CP), ether extract (EE) and mineral matter (MM) were carried out following the protocol described the methodology in Silva and Queiroz [7]. The analysis of neutral detergent fiber (NDF) and acid detergent fiber (ADF) using $\alpha$-amylase (Ankom Technology, Tecnoglobo Equipamentos Ltda.) and sodium sulfite [8]. Organic matter (OM) was calculated by subtracting MM from DM. Total carbohydrate levels (TCL) were mensured using the equation: TCL $=100-(\mathrm{CP}+\mathrm{EE}+\mathrm{MM})$ [9], while the levels of non-structural carbohydrates (NSC) were calculated by subtracting NDF from TCL (Table 2).

Samples were collected from each experimental ration (about $200 \mathrm{~g}$ ) to determine particle size by manual agitation using 19,8 and 1.18mm mesh sieves in a Penn State Particle Separator (Table 2). Physically effective NDF was estimated by multiplying the NDF concentration (\% DM) of the feed by the percentage of particles retained in sieves larger than $1.18 \mathrm{~mm} \mathrm{[10].}$

Milk production was measured on the 15th to 19th days of each sub-period and total production was determined by adding the morning and afternoon milking. It was used a milking machine (Westfalia RO), with a $120 \mathrm{ppm}$ pulse rate and $36 \mathrm{kPa}$ vacuum range, on a platform for 10 ewes. Feeding efficiency was expressed as $\mathrm{kg}$ of milk/kg of ingested DM.

The yields of fat-corrected milk (FCM 6.5\%) and fat and protein-corrected milk (FPCM 6.5\% and $5.8 \%$, respectively) were measured using the equation: FCM $(6.5 \%)=\mathrm{MY} \times(0.37+(0.097 \times \mathrm{F}))$; FPCM $(6.5 \%$ and $5.8 \%)=\mathrm{MY} \times(0.25+(0.085 \times \mathrm{F})+(0.035 \times \mathrm{P}))$. Where: MY: milk yield $(\mathrm{kg}) ; \mathrm{F}:$ fat $(\%)$, and P: protein (\%) $[11]$.

On the 20th and 21st days of each sub-period, one milk samples were collected from each milking in each shift (morning and afternoon)was used to determine its protein, fat, total solids and lactose content and somatic cell count.

\section{Statistical Analysis}

The data were subjected to analysis of variance and regression, using PROC GLM and PROC REG of the SAS ${ }^{\circ}$ statistical software. Tests for orthogonal polynomials (linear, quadratic and cubic) were applied whenever a treatment effect was observed at $5 \%$ probability.

The statistical model used was: Yijkl= $\mu+\mathrm{Qi}+\mathrm{Pj}+\mathrm{Tk}+\mathrm{Qi} * \mathrm{Tk}+\mathrm{E}$ (ijkl); where: Yijk= dependent variable, $\mu=$ overall mean, $\mathrm{Qi}=$ effect of square $\mathrm{i}, \mathrm{Pj}=$ effect of period $\mathrm{j}, \mathrm{Tk}=$ effect of treatment $\mathrm{k}, \mathrm{Q}{ }^{*} \mathrm{Tk}=$ interaction between square and treatment, $\mathrm{E}(\mathrm{ijkl})=$ experimental error associated with each observation.

The effects of the shifts and of the interaction between shift and treatment were also included for the analysis of milk components.

\section{RESULTS AND DISCUSSION}

Mean values for initial weight, final weight, metabolic weight, dry matter intake (DMI), milk production and feeding efficiency are presented in Table 3. There was no significant effect of NDF supply level on the animal weight variables.

A quadratic effect $(\mathrm{P}=0.02)$ was observed for $\mathrm{DMI}$, expressed as $\mathrm{kg} / \mathrm{day}$, in $\%$ of $\mathrm{BW}$ and metabolic weight unit, with maximum levels reached in diets with $37.8 \% \mathrm{NDF}$, which represented $1.76 \mathrm{~kg}$ of $\mathrm{DM}$. However, that higher intake did not reflect on milk production, as the highest milk production was observed in more energy-rich diets, with lower levels of NDF (23\%). Nevertheless, when DMI decreased (treatment $41 \%$ NDF) a reduction in milk production was observed as well.

The animals subjected to diet containing 23\% NDF showed lower DMI compared to animals from the treatment with $32 \%$ NDF. A likely explanation for that drop in intake may be related to the energy level of the diet with less roughage, which triggered the physiological control mechanism, in which animals ingest feed until satisfying their energy requirements.

The behavior observed in milk production was inverse to fiber concentration in diet. Thus, the increase in NDF levels in the diet showed a linear negative effect $(\mathrm{P}<0.01)$ on milk production, with maximum yield reached with the least fiber in the diet (23\%), equivalent to a roughage:concentrate ratio of 18:82. 
Possibly, the energy content of the diet, associated with dry matter intake which seems to have been restricted by the full reticulum-rumen, limited the yield of animals ingesting rations containing high levels of fiber. The amount of milk produced by ewes is influenced by diet [12]. While testing diets roughage:concentrate ratios of 80:20 and 60:40 in DM, those authors observed yields of 1.36 and $1.50 \mathrm{~kg}$ of milk/day, respectively.

Feeding efficiency, expressed as $\mathrm{kg}$ milk/kg of DMI, also showed a linear negative effect $(p \leq 0.02)$ as NDF levels in the diet increased, which may be related to higher intake of energy present in the diets with greater quantities of concentrate, rich in starch, allowing higher yields with lower intakes, when compared to diets with high rates of fiber.

A negative linear effect $(\mathrm{P}<0.01)$ was observed in milk production, fat-corrected milk production $(6.5 \%)$ and fat- and protein-corrected milk production $(6.5 \%$ and $5.8 \%)$ as fiber inclusion in the diet increased, which is not prevented, however, sheep who ingested $23 \%$ to $41 \%$ NDF.

Although literature data evidence the existence of a negative correlation between milk production and the amounts of its components [11], in the present experiment milk components followed the amounts of produced milk, decreasing as NDF levels in the diet increased.

The concentration (\%) of milk components did not change ( $p>0.05)$ in function of diet fiber levels (Table 4). This suggests that a reduction in fiber in the ration did not have a negative effect in the rumen or mammary gland. Other authors working with lactating ewes, did not observe effects of NDF levels in ration on the levels $(\%)$ of fat, lactose and total solids in milk [13].

According to the literature, the values observed for fat, protein, lactose, and total solids of this experiment (Table 4) are consistent with previously published values for Bergamasca ewes, with $4.8 \%$ of fat, $4,71 \%$ of protein, $4.87 \%$ of lactose and $14.88 \%$ of total solids to diet with $56 \%$ of NDF [14].

It is important to highlight that the fat level was adequate in all treatments, denoting the physical effectiveness of dietary fiber on the fat percentage of milk. Reducing diet fiber levels leads to a decrease in time spent chewing[3]. Consequently, there is an acidification of rumen $\mathrm{pH}$ because there is less saliva flowing to the rumen, reducing the flow of buffering substrate. This may hinder the growth of cellulolytic microorganisms and the acetate:propionate ratio, and thus affect the fat levels in milk. In the present study, it can be inferred that the diets containing the lowest NDF levels did not cause lack of effectiveness, given that the fat level was not influenced by fiber levels.

The ingestive behavior of ewes in this study showed that although diets with low fiber content have smaller particle sizes (Table 2), it can be assumed that the diets were capable of maintaining saliva production, keeping rumen $\mathrm{pH}$ stable and certainly not reaching values below 6.0, as the fat level of milk remained constant.

It is important to emphasize that no clinical sign of acidosis was observed throughout the experiment, indicating that diets were able maintain rumen health, supporting the hypothesis of functioning and healthy rumens with these diets. Moreover, the similar fat levels among treatments are a sign that all diets were sufficient to generate acetate, which is needed to synthesize short- and medium-chain fatty acids in mammary tissues.

Tables

Table 1: Chemical composition, percentage of ingredients and roughage:concentrate ration of the experimental diets

\begin{tabular}{|c|c|c|c|c|c|}
\hline & \multicolumn{5}{|c|}{ Treatments ${ }^{1}$} \\
\hline & $23 \%$ & $32 \%$ & $41 \%$ & $50 \%$ & $\mathbf{M R}^{2}$ \\
\hline \multicolumn{6}{|c|}{ Bromatological Composition } \\
\hline DM & 83.07 & 81.54 & 80.88 & 80.02 & 80.70 \\
\hline NDF & 24.14 & 32.80 & 40.81 & 50.70 & 28.77 \\
\hline $\mathrm{NDFfe}^{3}$ & 10.80 & 17.27 & 22.94 & 34.41 & - \\
\hline $\mathrm{ADF}$ & 8.70 & 14.65 & 22.02 & 28.35 & 7.33 \\
\hline LIG & 1.18 & 2.59 & 4.14 & 6.32 & 0.73 \\
\hline $\mathrm{CP}$ & 16,05 & 16.20 & 16.8 & 16.90 & 17.05 \\
\hline $\mathrm{EE}$ & 4.10 & 3.70 & 2.50 & 2.20 & 3.07 \\
\hline $\mathrm{MM}$ & 7.96 & 7.82 & 8.41 & 9.40 & 10.67 \\
\hline OM & 75.11 & 73.72 & 72.48 & 70.62 & 70.03 \\
\hline TCL & 71.58 & 71.95 & 71.06 & 70.46 & 66.48 \\
\hline NSC & 46.44 & 39.13 & 28.45 & 19.75 & 37.71 \\
\hline \multicolumn{6}{|c|}{ Percentage of Ingredients } \\
\hline A1falfa Hay & 18.20 & 39.35 & 63.75 & 88.10 & - \\
\hline Corn Grain & 65.01 & 48.20 & 28.80 & 9.45 & 10.79 \\
\hline Soybean Meal & 12.70 & 9.42 & 5.63 & 1.85 & 4.80 \\
\hline Cottonseed Meal & - & - & - & - & 84.10 \\
\hline Limestone & 1.64 & 1.21 & 0.73 & 0.24 & 0.31 \\
\hline Mineral Salt ${ }^{4}$ & 2.45 & 1.82 & 1.09 & 0.36 & - \\
\hline \multicolumn{6}{|c|}{ Roughage:Concentrate Ration } \\
\hline Roughage & 18 & 40 & 65 & 88 & - \\
\hline Concentrate & 82 & 60 & 35 & 12 & 100 \\
\hline
\end{tabular}


${ }^{1}$ Treatments: percentage of NDF in total ration: $25 \%, 32 \%, 41 \%$ and $50 \% ;{ }^{2}$ Ration given in the milking facility (100g/day/animal); ${ }^{3}$ Physically effective neutral detergent fiber; ${ }^{4}$ Composition: Ca-140g, Na-133g, P-80g, S12g, Mg-7g, Zn-4200mg, Fe-1500mg, F-800mg, Mn-800mg, Cu- 300mg, I-1500mg, Co- 100mg, Se-15 mg.

Table 2: Particle size of the experimental ration (\%DM1)

\begin{tabular}{lcccc}
\hline & \multicolumn{4}{c}{ Treatments2 } \\
\cline { 2 - 5 } & $\mathbf{2 3 \%}$ & $\mathbf{3 2 \%}$ & $\mathbf{4 1 \%}$ & $\mathbf{5 0 \%}$ \\
\hline Particle Size & & & & \\
$>19 \mathrm{~mm}$ & 0.06 & 0.27 & 0.61 & 2.86 \\
$>8 \mathrm{~mm}$ & 1.39 & 2.89 & 6.10 & 15.49 \\
$>1.18 \mathrm{~mm}$ & 43.27 & 49.51 & 49.51 & 49.52 \\
$<1.17 \mathrm{~mm}$ & 62.78 & 56.31 & 53.77 & 41.84 \\
\hline
\end{tabular}

${ }^{\mathrm{T}} \mathrm{DM} \%$ :Dry Matter; ${ }^{2}$ Treatments: percentage of NDF in total ration: $25 \%, 32 \%, 41 \%$ and $50 \%$

Table3: Body weight (BW), dry matter intake (DMI), milk production and feeding efficiency of Bergamasca ewes under ration with four NDF leves

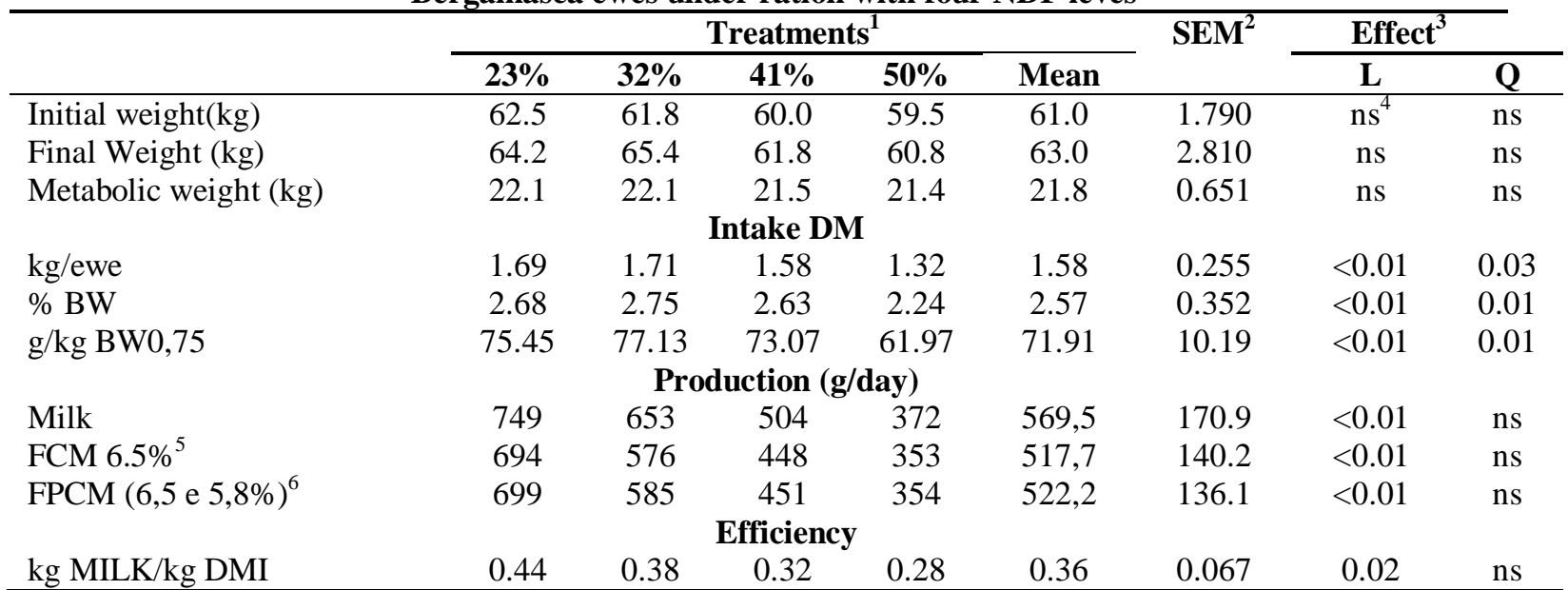

${ }^{1}$ Treatments: percentage of NDF in total ration: $25 \%, 32 \%, 41 \%$ and $50 \%,{ }^{2}$ SEM: standardized error mean, ${ }^{3}$ Effect $\mathrm{P}$ value for orthogonal polynomial test lecturing Linear $(\mathrm{L})$ or Quadratic $(\mathrm{Q})$ response; ; ${ }^{4}$ Not significant ${ }^{5} \mathrm{FCM}$ : Fat-corrected milk (6.5\%); ${ }^{6} \mathrm{FPCM}$ : Fat-corrected milk (6.4\%) and production-corrected milk (5.8\%)

Table4: Mean daily levels for milk composition from Bergamasca ewes under ration with four levels of NDF

\begin{tabular}{|c|c|c|c|c|c|c|c|c|}
\hline \multirow{2}{*}{ Variable } & \multicolumn{4}{|c|}{ Treatments $^{1}$} & \multirow[b]{2}{*}{ Mean } & \multirow{2}{*}{ SEM $^{2}$} & \multicolumn{2}{|c|}{ Effects $^{3}$} \\
\hline & $23 \%$ & $32 \%$ & $41 \%$ & $50 \%$ & & & $\mathbf{L}$ & $\mathbf{Q}$ \\
\hline \multicolumn{9}{|c|}{ Fat } \\
\hline$\% /$ day & 6.17 & 5.97 & 5.73 & 5.29 & 5.79 & 1.588 & $\mathrm{~ns}^{4}$ & $\mathrm{~ns}$ \\
\hline \multicolumn{9}{|c|}{ Protein } \\
\hline$\% /$ day & 5.68 & 5.65 & 5.51 & 5.46 & 5.58 & 0.455 & $\mathrm{~ns}$ & $\mathrm{~ns}$ \\
\hline \multicolumn{9}{|c|}{ Lactose } \\
\hline$\% /$ day & 4.73 & 4.68 & 4.55 & 4.50 & 4.62 & 0.334 & ns & $\mathrm{ns}$ \\
\hline \multicolumn{9}{|c|}{ Total Solids } \\
\hline$\% /$ day & 17.26 & 17.04 & 16.76 & 16.70 & 16.94 & 1.689 & $\mathrm{~ns}$ & $\mathrm{~ns}$ \\
\hline \multicolumn{9}{|c|}{ Defatted Solid Extract } \\
\hline$\% /$ day & 11.40 & 11.31 & 11.17 & 11.09 & 11.24 & 0.390 & $\mathrm{~ns}$ & $\mathrm{~ns}$ \\
\hline
\end{tabular}

${ }^{1}$ Treatments: percentage of NDF in total ration: $25 \%, 32 \%, 41 \%$ and $50 \%,{ }^{2}$ SEM: standardized error mean,

${ }^{3}$ Effect $\mathrm{P}$ value for orthogonal polynomial test lecturing Linear (L) or Quadratic (Q) response; ${ }^{4}$ Not significant

\section{CONCLUSION}

The increase in NDF levels in diets may have reduced total milk production, but did not alter the chemical characteristics of milk.

NDF levels may influence dry matter intake, therefore, under production and nutritional aspects, fiber levels around $37 \%$ NDF are recommended for dairy ewe diets, when particle size is finely chopped. 


\section{Acknowledgements}

The authors are grateful to State of Sao Paulo Research Foundation (FAPESP) for the financial support.

\section{REFERENCES}

[1] L.G. Nussio, F.P. Campos, M.L. Lima, M.L. Metabolismo de carboidratos estruturais, in: Berchielli, T.T., Pires, A.V., Oliveira, G.S. (Eds.), Nutrição de ruminantes. (FUNEP, Jaboticabal, 2006) 182-228.

[2] S. Carvalho, M.T. Rodrigues, R.H. Branco. Consumo de nutrientes, produção e composição do leite de cabras Alpinas alimentadas com dietas contendo diferentes teores de fibra. Rev. Bras. Zootecn., 35, 2006, 1153-1161.

[3] B.P. Lammers, D.R. Buckmaster and A.J. Heinrichs. A simple method for the analysis of particle sizes of forage and total mixed rations. J. Dairy Sci., 79, 1996, 922- 928.

[4] S.T. Woodford and M.R. Murphy. Effect of forage physical form on chewing activity, dry matter intake, and rumen function of dairy cows in early lactation. J. Dairy Sci., 71, 1988, 674-686.

[5] J.M. Forbes. Voluntary feed intake, in: Dijkstra, J., Forbes, J.M., France, J. (Eds.), Quantitative aspects of ruminant digestion and metabolism, 2 (CABI Publishing, Cambridge,2007) 13-47.

[6] NRC (National Research Council), Nutrient Requirements of Small Ruminants: Sheep, Goats Cervids and New World Camelids, (National Academy Press, Washington, DC, 2007).

[7] D.J. Silva and A.C. Queiroz, Análise de Alimentos: Métodos Químicos e Biológicos (third Ed. UFV: Viçosa, 2002).

[8] P.J. Van Soest, J.B. Robertson and B.A. Lewis. Methods for dietary fiber, neutral detergent fiber, and nonstarch polysaccharides in relation to animal nutrition. J. Dairy Sci. 74, 1991, 3583-3597.

[9] C.J. Sniffen, J.D. O'connor and P.J. Van Soest. A net carbohydrate and protein system for evaluating cattle diets: II. Carbohydrate and protein availability. J. Anim. Sci. 70, 1992, 3562-3577.

[10] D. R. Mertens. Creating a system for meeting the fiber requirements of dairy cows. J. Dairy Sci. 80, $1997,1463-1481$.

[11] G. Pulina and A. Nudda. Milk production, in: Pulina, G. (Eds.), Dairy sheep nutrition. (CABI Publishing, Sassari, 2004$) 11-27$.

[12] C. C. Zeppenfeld, C.C. Pires, L. Müller, L.S. Vollenhaupet, M.A. Cunha and S.L.P. Medeiros. Efeito de diferentes níveis de concentrado no desempenho de ovelhas lactantes e suas cordeiras. Rev. Norte, 4, 2005, 1-7.

[13] C. H. Hübner, C.C. Pires, D.G. Galvani, S. Carvalhoand T.P. Wommer. Consumo de nutriente, produção e composição do leite de ovelhas alimentadas com dietas contendo diferentes níveis de fibra em detergente neutro. Rev. Bras. Zootecn. 36, $2007,1882-1888$.

[14] E. O. Queiroz, E.R. Siqueira, C. C. Boucinhas, A. S. Natel, D.P. Oliveira, L. C. Vieira Júnior. Composição centecimal do leite e incidência de mastite em ovelhas da raça Bergamácia mantidas em pasto ou confinamento. Public. Med. Vet. E Zootec, 6, $2012,1351$. 